\title{
Chromium-Containing Organic Fertilizers from Tanned Hides and Skins: A Review on Chemical, Environmental, Agronomical and Legislative Aspects
}

\author{
Claudio Ciavatta ${ }^{1}$, Chiara Manoli ${ }^{2}$, Luciano Cavani ${ }^{1}$, Clizia Franceschi ${ }^{2}$, Paolo Sequi ${ }^{3}$ \\ ${ }^{1}$ Department of Agro-Environmental Science and Technology, University of Bologna, Bologna, Italy; ${ }^{2}$ ILSA SpA, Arzignano, Italy; \\ ${ }^{3}$ Agricultural Research Council, Research Center for the Soil-Plant System, Roma, Italy. \\ Email: claudio.ciavatta@unibo.it
}

Received July 28 ${ }^{\text {th }}$, 2012; revised August 27 ${ }^{\text {th }}$, 2012; accepted September $28^{\text {th }}, 2012$

\begin{abstract}
A category of chromium (Cr)-containing fertilizers is represented by the fertilizers deriving from byproducts of tanning process. Their use is widespread because of their good agronomic response due to the high content of slow release organic nitrogen $(\mathrm{N})$ and carbon $(\mathrm{C})$. They do not represent an environmental hazard because only the non-toxic form of $\mathrm{Cr}(\mathrm{III})$ is present. Productive processes may involve chemical, enzymatic or thermal hydrolysis. The final product is characterized by different contents of peptides and free amino acids depending on the type of hydrolysis. Legislation concerning Cr-containing fertilizers is controversial because often do not consider any scientific evidences; nevertheless, the European Union, the United States and countries as Italy, do not set the restriction to $\mathrm{Cr}(\mathrm{III})$ and generally only the presence of the toxic form, $\mathrm{Cr}(\mathrm{VI})$, is limited. Depending on its two main oxidation forms, $\mathrm{Cr}$ issue has been studied for many years. Several authors confirmed that $\mathrm{Cr}(\mathrm{VI})$ is carcinogenic, while $\mathrm{Cr}(\mathrm{III})$ is an essential trace element in human and animal diet. In soil $\mathrm{Cr}(\mathrm{III})$ has low mobility, whereas $\mathrm{Cr}(\mathrm{VI})$ is highly water soluble. However $\mathrm{Cr}(\mathrm{VI})$ in soil is quickly reduced to $\mathrm{Cr}(\mathrm{III})$; on the contrary oxidation of $\mathrm{Cr}(\mathrm{III})$ to $\mathrm{Cr}(\mathrm{VI})$ is rarely possible because particular conditions must occur. Only a very small fraction of $\mathrm{Cr}$ in soil is available to plant uptake and its translocation in edible parts is limited because it is immobilized in roots as $\mathrm{Cr}(\mathrm{III})$. Therefore risks of environmental pollution using these fertilizers are negligible; on the contrary they have positive environmental and agronomical effects. The aim of this review is to deal with the category of the organic fertilizers containing Cr derived from tannery processes focusing on its chemical, productive, legislative, environmental and agronomical aspects. Special attention is given to the ambiguous issue of $\mathrm{Cr}$ briefly summarizing the most important studies of the last forty years.
\end{abstract}

Keywords: Organic Fertilizers; Tanned Hides and Skins; Hydrolyzed Leather; Trivalent Chromium; Hexavalent Chromium; Soil

\section{Introduction}

Chromium (Cr) issue has represented a major area of concern for many years due to the dual chemical behavior of its two main oxidation forms: trivalent form, $\mathrm{Cr}(\mathrm{III})$, is considered an essential trace element in human and animal nutrition, whereas hexavalent form, $\mathrm{Cr}(\mathrm{VI})$, is extremely toxic to animals and humans and is considered cause of cancer [1].

A category of Cr-containing fertilizers is produced using byproducts of tanning process originated from tanned animal hides. These fertilizers contain $\mathrm{Cr}$ only in its trivalent form [Cr(III)] [2,3]. They represent an efficient tool for both conventional and organic farming thanks to their high content in organic nitrogen $(\mathrm{N})$ and carbon $(\mathrm{C})$ and their capacity to release mineral $\mathrm{N}$ slowly following the environmental conditions and plant needs [3,4].

Legislations of the European Union [5], United States $[6,7]$ and of countries such as Italy [8] permit the unlimited use of Cr-containing fertilizers; otherwise in some countries limits are generically referred to total $\mathrm{Cr}$ preventing their use because they consider them as a risk for the environment and human health. Even in European Union, for compost and other fertilizers included in the recovery program called "End of Waste", $\mathrm{Cr}$ is estimated as total Cr, and the thresholds of content are rather low, so that the name of the program becomes a real contradiction.

The aim of this review is to deal with the category of the organic fertilizers containing $\mathrm{Cr}$ derived from tannery process focusing on its chemical, productive, legislative, environmental and agronomical aspects. Special attention 
is given to the ambiguous issue of $\mathrm{Cr}$ briefly summarizeing the most important studies of the last forty years with the purpose to explain the non-toxicity of $\mathrm{Cr}$ contained in these fertilizers and the negligible probability that exogenous $\mathrm{Cr}$ introduced in soil through fertilization is oxidized in the toxic form of $\mathrm{Cr}(\mathrm{VI})$. Of course, a further aim is to give a contribution to a correct evaluation of the possible toxicity of $\mathrm{Cr}$ in other fertilizers.

\section{Cr-Containing Organic Fertilizers: Typologies and Characterization}

Cr-containing fertilizers are a wide and diversified group of products, including organic fertilizers, organic amendments, limestone, sewage and tannery sludges. The presence of heavy metals, such as $\mathrm{Cr}$, mainly depends on both the type of fertilizer and the matrices used in the production $[9,10]$.

A category of Cr-containing fertilizers is represented by the organic fertilizers deriving from tannery industries. They are produced using by-products of the intermediary stages of the tanning process as "wet blue", "pickled pelts" and "limed hides". Raw materials are constituted by shaves and trimmings of hides and skins. The presence of $\mathrm{Cr}$ in the final product is due to the tanning process that in nearly all cases is made using $\mathrm{Cr}$ salts $\left[\mathrm{Cr}_{2}\left(\mathrm{SO}_{4}\right)_{3}\right]$ as tanning agents in order to stabilize the proteins to chemical, thermal and biological degradation.

$\mathrm{Cr}$ contained in the fertilizers is only in the non-toxic form, that is $\operatorname{Cr}(\mathrm{III})[2,3]$ with values between $0.5 \%$ and $3 \%$ in solid fertilizers [2-4]. The presence of $\mathrm{Cr}$ in fluid fertilizers becomes negligible after the process of the suspension to a solution product.

The use of these fertilizers is widespread because of their good agronomic response due to their high content of organic $\mathrm{C}$ and $\mathrm{N}$ : in fact this type of organic fertilizers is characterized by a high organic $\mathrm{C}$ content (average value of $38 \%-50 \%$ ) and by a large amount of organic $\mathrm{N}$ (average value of $8 \%-13 \%$ ) [4]. These products also contain other nutrients essential to plant nutrition such as phosphorus (P), potassium (K), sulphur (S), calcium (Ca), magnesium (Mg) and micronutrients such as iron $(\mathrm{Fe})$, manganese $(\mathrm{Mn})$, copper $(\mathrm{Cu})$ and zinc $(\mathrm{Zn})$, which are not present in sufficient quantities to be declared on the fertilizer label (Legislative Decree No. 75/2010) [8], and the total content of heavy metals well known as pollutants i.e., arsenic (As), cadmium (Cd), mercury (Hg), nickel $(\mathrm{Ni})$ and lead $(\mathrm{Pb})$ is lower than the legal limit settled by the Legislative Decree No. 75/2010 [3,4,8,10].

\section{Productive Processes}

Productive processes developed by manufacturers involve three kinds of hydrolysis (Figure 1): chemical (in acid or alkaline solutions), enzymatic and thermal.

Generally the process includes several phases concerning a first step of preparation of the raw material, defined as homogenization, followed by the hydrolysis and some operations necessary to standardize the product obtained.

In particular if the chemical hydrolysis is carried out with acid or alkaline solution, the raw material treated with hot water and/or diluted acid and/or diluted alkaline solutions, undergoes a phase of heating at temperatures ranging between $40^{\circ} \mathrm{C}$ and $100^{\circ} \mathrm{C}$ for at least 1 hour. The heat treatment permits to extract peptides and amino acids and to separate fatty materials. When extraction ends, the material is a neutral liquid that is collected and concentrated in order to obtain liquid fertilizers with an average content of organic nitrogen of $5 \%-9 \%$. The content of free amino acids may be high or low depending on the production process: in particular if process includes high temperature and long time of extraction, the final amount of free amino acids will be higher than of long chain peptides.

When hydrolysis is enzymatic the raw material undergoes an extraction at a lower temperature than the chemical extraction (generally $40^{\circ} \mathrm{C}-60^{\circ} \mathrm{C}$ ). Consequently time of extraction is longer, lasting 2 - 12 hours. Extraction occurs using proteolytic enzymes, as endoproteases that derived from not genetically modified organisms. Extraction is followed by a phase of concentration that leads the liquid to obtain an average content of organic $\mathrm{N}$ of $9 \%$. This kind of hydrolysis permits to obtain a fertilizer characterized by a high content of polypeptides, peptides and amino acids. The content of free amino acids and the molecular weight of the organic compounds depend on both hydrolysis intensity and the raw material used. Stability of the product is ensured both by the origin of the byproducts and by the specific plant cleaning process.

Finally the thermal hydrolysis consists of an hour and a half phase of heating at an average temperature of $160^{\circ} \mathrm{C}$. Differently from the former two hydrolysis before described, the final product is dried to obtain a solid fertilizer containing an average content of organic $\mathrm{N}$ of $12 \%$. As well as for the enzymatic hydrolysis, the molecular weight of the organic compounds depends on hydrolysis intensity and the raw material used.

The purpose of the following stages is to refine the product: it is inactivated the hydrolyzing agent in case of enzymatic extraction, if necessary $\mathrm{pH}$ is modified as required in the final product and it is clarified by filtration. Finally the solution is concentrated to obtain the required $\mathrm{N}$ content in the final product and in case of powder formulation is dried. 


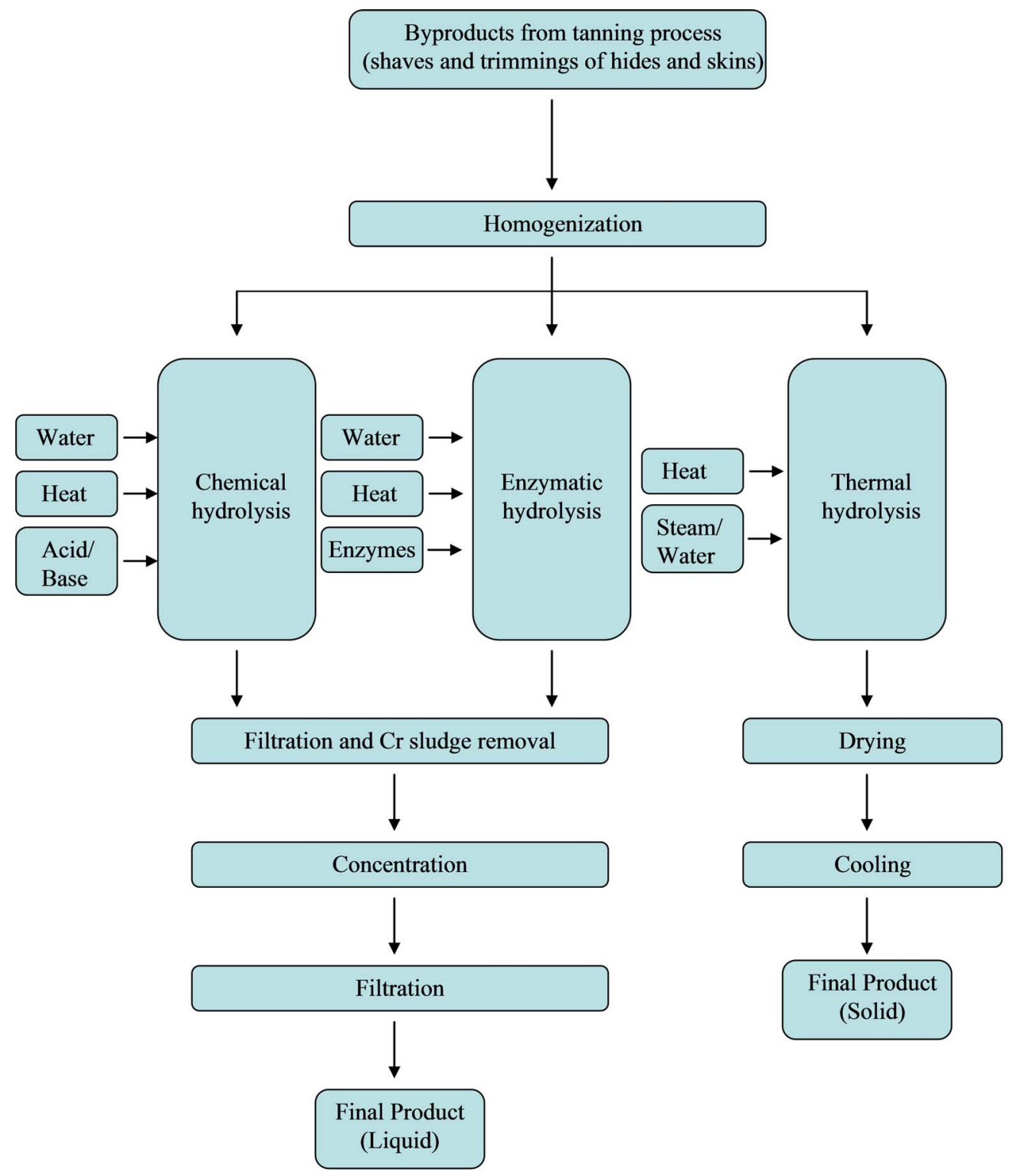

Figure 1. Flow chart of the different productive processes of $\mathrm{Cr}$-containing fertilizers.

\section{Legislations}

In terms of legislation the issue of $\mathrm{Cr}$ contained in fertileizers remains controversial because often the determination of the maximum admissible levels does not consider any scientific and experimental evidences. In particular the maximum admissible levels fixed in most countries frequently do not distinguish the oxidation state of $\mathrm{Cr}$ and both $\mathrm{Cr}(\mathrm{VI})$ and $\mathrm{Cr}(\mathrm{III})$ forms are considered as hazardous and toxic.

Another controversial issue is the classification of the different types of $\mathrm{Cr}$-containing organic fertilizers or soil conditioners in the different countries. Basically $\mathrm{Cr}$ may be contained both in mineral and organic fertilizers: high concentrations of $\mathrm{Cr}$ may be present naturally in mineral fertilizers extracted from mines; organic fertilizers or soil conditioners which may contain $\mathrm{Cr}$ include on one hand municipal sewage sludge (biosolids), municipal solid waste, on the other hand tannery byproducts [11].

The European Union, the United States and other countries as well as Italy that have been deeply dealt with the issue of $\mathrm{Cr}$, have legislations in which the maximum admissible levels of $\mathrm{Cr}$ in these fertilizers are only referred to $\mathrm{Cr}(\mathrm{VI})$, while $\mathrm{Cr}(\mathrm{III})$ is generally allowed with no restriction basing on the literature that considers it as no hazardous.

In particular the European Union in the Annex I of the Regulation (EC) 889/2008 [5], laying down detailed rules on organic production, considers these kind of or- 
ganic fertilizers as "fur" in the category of products or byproducts of animal origin. In the same regulation, the maximum concentration in $\mathrm{mg} / \mathrm{kg}$ of dry matter of $\mathrm{Cr}(\mathrm{VI})$ in fur is equal to zero (i.e. less than the detection limit of the analytical method used).

In Europe, the tendency in the near future seems to modify limits for heavy metals (i.e. As, $\mathrm{Cd}, \mathrm{Hg}, \mathrm{Ni}, \mathrm{Pb}$ ) including $\mathrm{Cr}(\mathrm{VI})$ whose maximum concentration allowed in fertilizers should be raised to $2 \mathrm{mg} / \mathrm{kg}$ (value expressed on dry matter basis): restrictions should be limited at $\operatorname{Cr}(\mathrm{VI})$, whereas the $\mathrm{Cr}(\mathrm{III})$ content will remain unlimited [12].

In Italy, where there are some districts in which tanning has practiced for a long time, "fur" is subdivided in several denominations including hydrolyzed products which differ in the raw materials and the process of hydrolysis (Annex I of the Legislative Decree No. 75/2010) [8]. For these fertilizers belonging to the class of nitrogenous organic fertilizers the maximum concentration (mg/kg of dry matter) of $\mathrm{Cr}(\mathrm{VI})$ is defined as equal to zero (i.e. less than the detection limit of the analytical method-Annex XIII of the Legislative Decree No. 75/2010) [8] . In addition, only for the hydrolyzed leather the extracted $\mathrm{Cr}$ content in DTPA solution must be less than $1,800 \mathrm{mg} / \mathrm{kg}$ (Annex I of the Legislative Decree No. 75/2010) [8].

The Environmental Protection Agency (EPA) of the United States defines the levels of the heavy metals in the biosolids using 14 cycles for evaluating the risk. Concerning Cr applied to soil through biosolids and fertilizers, EPA established that it does not represent either an environmental nor sanitary risk [13]. In 1993 EPA published the "Standards for the use or disposal of sewage sludge (40 CFR Part 503)” [6]. In 1994 EPA decided to delete the pollutant limits for $\mathrm{Cr}$ in subpart B (Land application) at point 503.13. EPA concluded that there is no current basis for establishing land application pollutant limits for $\mathrm{Cr}$ for the following reasons: "the Agency has determined that there is an insufficient basis at this time for the regulation of $\mathrm{Cr}$ in sewage sludge that is applied to the land. This determination is confirmed by EPA's review of new information concerning $\mathrm{Cr}$ and the land application of sewage sludge. Consequently the Agency is amending Tables 1-4 (see 40 CFR Part 503 [6]) to delete $\mathrm{Cr}$ from the regulated metals for the following reasons. First EPA has reaffirmed its determination that $\mathrm{Cr}$ in sewage sludge appears predominantly in the trivalent form for which the likelihood of plant injury is substantially lower than the likelihood of plant injury from $\mathrm{Cr}$ in the hexavalent form. Second, in addition to reexamining the rulemaking record, EPA obtained more recent data from field studies of crops grown on soil to which sewage sludge had been applied. These data are similar to those used in the final rule for evaluating the potential for plant injury from the $\mathrm{Cr}$ in sewage sludge. EPA evaluated these data using the same statistical methods used for the final rule to assess the potential for plant injury. Like the earlier data, these data show no relationship between plant injury associated with $\mathrm{Cr}$ in sewage sludge at high loading rates. Finally, to confirm its determination that data do not support regulation of $\mathrm{Cr}$ at this juncture, EPA also took a second look at other pathways of exposure. After the plant toxicity pathway, the next significant pathway of concern is the risk associated with exposure of a tractor operator to $\mathrm{Cr}$ from sewage sludge in the dust churned up by the tractor. EPA reevaluated this pathway using current National Institute of Occupational Safety and Health (NIOSH) standards for worker exposure to trivalent Cr. EPA's second look at the tractor operator exposure pathway determined that the appropriate risk-based limit for this pathway is well in excess of its earlier finding of $5000 \mathrm{mg} / \mathrm{kg}$. The limit for this pathway using the updated NIOSH standard is almost two orders of magnitude in excess of the observed 99th percentile concentration for $\mathrm{Cr}$ in the National Sewage Sludge Survey (NSSS). Given the fact that $\mathrm{Cr}$ limit for the next pathway of exposure-the ground-water pathway-is an order of magnitude greater than the 99th percentile sewage sludge concentration, EPA determined that it did not have data that justify regulation of $\mathrm{Cr}$ in land applied sewage sludge at this juncture. Applying the same criteria used for the final rule to determine whether to regulate a particular pollutant, EPA concluded that there is no current basis for establishing land application pollutant limits for $\mathrm{Cr}$ based on the tractor operator pathway or the ground-water pathway" [7].

\section{Chromium Issue}

Chromium is a transition metal and it is a member of group VI of the periodic table. It has a wide range of oxidation states (from $\mathrm{Cr}-2$ to $\mathrm{Cr}+6$ ), most commonly occurring as $\mathrm{Cr}(0), \mathrm{Cr}(\mathrm{II}), \mathrm{Cr}(\mathrm{III})$ and $\mathrm{Cr}(\mathrm{VI})$. Considering the rare occurrence of $\operatorname{Cr}(0)$, used only in the steel industry, and the less stability of divalent form which is rapidly oxidized to trivalent form, the most common oxidation states in nature are $\mathrm{Cr}(\mathrm{III})$ and $\mathrm{Cr}(\mathrm{VI})$ [14] .

Chromium(III) is considered the most stable and important oxidation state of $\mathrm{Cr}[1,15,16]$. The ion does not exist in solution because it forms complexes persisting even when thermodynamic conditions are not stable: in acid solution it is complexed with water or other anions, while in alkaline solutions it forms compounds which precipitate in time. [16].

Chromium(VI), on the contrary, is a strong oxidizing agent, relatively stable in water. It is almost always found 
linked to oxygen [15]. Its species are anionic and contribute to its much greater mobility and bioavailability than $\mathrm{Cr}(\mathrm{III})$ [17].

The average concentration of $\mathrm{Cr}$ in rocks is $100 \mathrm{mg} / \mathrm{kg}$ [15]. The grand mean of $\mathrm{Cr}$ concentrations in surface soils reported in the literature is different, also depending on the geographical area: $37 \mathrm{mg} / \mathrm{kg}$ [14], $54 \mathrm{mg} / \mathrm{kg}$ [9,15], $84 \mathrm{mg} / \mathrm{kg}[15,18]$. The range of $\mathrm{Cr}$ in soils varies from 1 to $1500 \mathrm{mg} / \mathrm{kg}$ [19]. Chromium is particularly concentrated in soils derived from basalt or serpentine rocks [14], where concentration can range from 2500 to 4000 $\mathrm{mg} / \mathrm{kg}$ [20] and even much more.

Chromium is produced from the ore chromite $[1,21]$ and is mainly used in metallurgy (production of stainless steel and alloys), refractory (production of bricks for furnaces) and chemical industries (pigments, wood preservatives and tanning leather) $[15,20,21]$.

\subsection{Chemical Behavior in Soil}

Chromium is commonly present in soil as $\mathrm{Cr}(\mathrm{III})$ and $\mathrm{Cr}(\mathrm{VI})$. Its behavior in soil depends on several factors, mainly $\mathrm{pH}$ and redox potential, oxidation state, presence of organic matter or minerals (e.g. manganese), electron donors or acceptors, competing ions, complexing agents [20]. The distribution of the trivalent and hexavalent forms in soil solution is the result of the interaction between $\mathrm{pH}$ and redox potential $[15,17,22]$, as shown in Figure 2.

Inorganic $\mathrm{Cr}(\mathrm{III})$ form is limited at $\mathrm{pH}$ values less than 5 , while above $\mathrm{pH} 5 \mathrm{Cr}(\mathrm{III})$ is hydrolyzed and the cationic species deriving from the hydrolysis are characterized by low solubility: this is the main reason why, in normal soil conditions, $\mathrm{Cr}$ (III) has low mobility and bioavailability [15,17,21,23].

Adsorption of $\mathrm{Cr}(\mathrm{III})$ is mainly influenced by $\mathrm{pH}$,

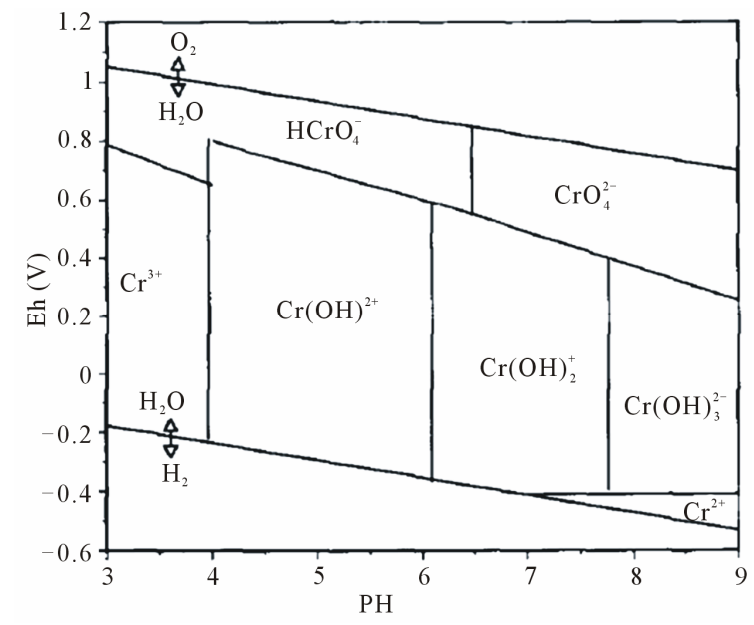

Figure 2. Eh-pH diagram showing the aqueous inorganic $\mathrm{Cr}$ species in soil-water environments [17]. cation exchange capacity, the presence of $\mathrm{Fe}$ and $\mathrm{Mn}$ oxides, organic matter and competitors. It is $\mathrm{pH}$-dependent because when $\mathrm{pH}$ increases, adsorption increases due both to the increase of the negative surface charges [24] of the soil and to the cation exchange reactions of the $\mathrm{Cr}(\mathrm{III})$ hydrolyzed species [20]. At the same time $\mathrm{Cr}$ (III) adsorption is increased by the presence of organic matter and clay minerals carrying superficial negative functional groups. Moreover the presence of $\mathrm{Fe}$ and $\mathrm{Mn}$ oxides affects adsorption, being $\mathrm{Cr}(\mathrm{III})$ a cationic metal. On the contrary adsorption decreases when in solution are present competing cations or are dissolved organic ligands $[15,20]$.

Inorganic form of $\mathrm{Cr}(\mathrm{VI})$, that is chromate (mainly present as $\mathrm{HCrO}_{4}^{-}$at $\mathrm{pH}$ less than 6 and $\mathrm{CrO}_{4}^{2-}$ above $\mathrm{pH} \mathrm{6),} \mathrm{is} \mathrm{highly} \mathrm{water} \mathrm{soluble} \mathrm{and} \mathrm{is} \mathrm{a} \mathrm{strong} \mathrm{oxidizing}$ agent due to its high positive reduction potential. As a consequence, it is a highly mobile and toxic form of $\mathrm{Cr}$ $[17,21,23]$.

Adsorption is less influenced by organic matter content and $\mathrm{pH}$ than $\mathrm{Cr}(\mathrm{III})$ [24], even if adsorption is favored under acidic to neutral $\mathrm{pH}$ because positive charges on soil colloids increase $[25,26]$ and ends when $\mathrm{pH}$ is above 8.5 [20]. $\mathrm{Cr}(\mathrm{VI})$ species $\left(\mathrm{HCrO}_{4}^{-}\right.$and $\mathrm{CrO}_{4}^{2-}$ ) adsorption proceeds at a lower rate than $\mathrm{Cr}$ (III) hydrolyzed species [26]. They are adsorbed by soil phases having exposed hydroxyl groups on their surfaces, such as $\mathrm{Mn}, \mathrm{Fe}$ and $\mathrm{Al}$ oxides that are characterized by their high positive charge $[20,24,25]$.

The presence of $\mathrm{Cr}(\mathrm{III})$ or $\mathrm{Cr}(\mathrm{VI})$ in soil depends on the balance between oxidation and reduction reactions due to a Mn redox cycle and to the oxidation of organic matter [27]. In a natural environment $\mathrm{Cr}(\mathrm{VI})$ can be reduced to $\mathrm{Cr}$ (III) in the presence of electron donors (reductants) such as organic matter, $\mathrm{Fe}(\mathrm{II})$ and sulfides $[20,27]$. Reduction of $\mathrm{Cr}(\mathrm{VI})$ to $\mathrm{Cr}(\mathrm{III})$ is $\mathrm{pH}$-dependent, increasing with lower $\mathrm{pH}$ values [26]. Organic reductants of $\mathrm{Cr}(\mathrm{VI})$, such as organisms and residual organic materials, in presence of soluble organic chelating agents may form soluble chelated complexes with $\mathrm{Cr}$ (III) [17], thus enhancing the potential for re-oxidation to $\mathrm{Cr}(\mathrm{VI})$ by $\mathrm{Mn}$ oxides. However when $\mathrm{Cr}(\mathrm{III})$ is bound to organic complexes in soil, it becomes immobile or insoluble [25]. On the contrary inorganic oxidants, such as Fe(II) species, reduce $\mathrm{Cr}(\mathrm{VI})$ concentration and simultaneously decrease the possibility of a transformation back to $\mathrm{Cr}(\mathrm{VI})$ because liquid $\mathrm{Cr}(\mathrm{III})$ is included in $\mathrm{Fe}, \mathrm{Cr}(\mathrm{OH})_{3}$ solids characterized by low solubility. Moreover, formation of solid Cr(III) phase will greatly diminish the potential for transformation back to $\mathrm{Cr}(\mathrm{VI})$ [17].

Differently by the many potential mechanisms responsible of reduction of $\mathrm{Cr}(\mathrm{VI})$ to $\mathrm{Cr}(\mathrm{III})$, the opposite reaction is possible only when particular conditions occur. In 
fact in natural environment $\mathrm{Cr}(\mathrm{III})$ can be oxidised to $\mathrm{Cr}(\mathrm{VI})$ only in the presence of electron acceptors (strong oxidants), such as $\mathrm{O}_{2}$ and high-valence $\mathrm{Mn}$ oxides [23]. However it was found that Mn oxides represent the only naturally occurring oxidant of $\operatorname{Cr}(\mathrm{III})[17,23]$; as a consequence their presence is essential because they serve as electron acceptors in the oxidation reaction [20]. However oxidation should occur with the simultaneous presence of other factors, such as low organic matter content, alkaline $\mathrm{pH}$ and high redox potential values [17,23]: all these conditions limit greatly the possibility of oxidation that represents a serious hazard for the environment. Moreover oxidation of $\mathrm{Cr}(\mathrm{III})$ to $\mathrm{Cr}(\mathrm{VI})$ is a phenomenon occurring very rarely even in the presence of $\mathrm{Mn}$ oxides and favorable $\mathrm{pH}$ conditions, due to the poor availability of mobile $\mathrm{Cr}(\mathrm{III})$ : exchangeable trivalent $\mathrm{Cr}(\mathrm{III})$ is practically inexistent in soil where the $\mathrm{pH}$ overcomes 5 [25, 26]. Furthermore the oxidation process is even slower when the Cr(III) species applied to the soil are exogenous and originated from tannery sludge amendments if compared to pure chemical forms of $\mathrm{Cr}(\mathrm{III})$ [26].

\subsection{Chromium in Plants}

Chromium is a non-essential element for plant growth and development $[26,28]$. Nevertheless it is absorbed by plants and the impact on the physiology of plants depends on Cr oxidation state, responsible of its fate and the resultant toxicity in plants [29]. Studies showed that $\mathrm{Cr}$ valence does not influence the absorption rate and both $\mathrm{Cr}(\mathrm{III})$ and $\mathrm{Cr}(\mathrm{VI})$ are of nearly equal availability to plants [30]. Generally, only a very small fraction of the total $\mathrm{Cr}$ content of soil is available to plant [26]. Exogenous applications of $\mathrm{Cr}(\mathrm{VI})$ to soil do not increase the concentration of soluble $\mathrm{Cr}$ in soil because reversion in unavailable forms to plants goes on at least one growing season [22].

Chromium may be absorbed by plant roots as $\mathrm{Cr}(\mathrm{III})$ or $\mathrm{Cr}(\mathrm{VI})$, it is poorly translocated and largely retained in roots, independently of $\mathrm{Cr}$ form that has been taken up [26,31,32]. The two ions do not share a common uptake mechanism: the uptake of $\mathrm{Cr}(\mathrm{III})$ is largely a passive process, whereas the uptake of $\mathrm{Cr}(\mathrm{VI})$ is mediated by low affinity sulphate carriers, specific for the uptake of essential metals $[29,30,33,34]$ and quickly converted to $\mathrm{Cr}(\mathrm{III})$ in roots by $\mathrm{Fe}(\mathrm{III})$ reductase enzymes [31].

Translocation of both Cr forms from roots to shoots is extremely limited: $\mathrm{Cr}(\mathrm{III})$ and $\mathrm{Cr}(\mathrm{VI})$ enter in the vascular tissue with difficulty. However, once in the xylem, $\mathrm{Cr}$ moves more readily [26,29,33,34]: very little translocation of $\mathrm{Cr}$ to the shoot is expected to occur when plants are supplied with either form of $\mathrm{Cr}$. In fact conversion of $\mathrm{Cr}(\mathrm{VI})$ to $\mathrm{Cr}(\mathrm{III})$ occurs in the roots where $\mathrm{Cr}(\mathrm{III})$ is the most predominant form: once $\mathrm{Cr}$ is transformed, translocation is very little, being $\mathrm{Cr}(\mathrm{III})$ a form with low solubility [26,31].

Roots accumulate $\mathrm{Cr}$ in a quantity 10 - 100 folds more than shoots independently on $\mathrm{Cr}$ state [31,33]. This preferential distribution is stable and does not depend on either its concentration nor soil properties [29]. For example in bean, only $0.1 \%$ of the total $\mathrm{Cr}$ accumulated was found in the seeds while $98 \%$ remained in the roots [29, 33]. Even though the tendency to retain $\mathrm{Cr}$ in roots is common to all plant species studied thus far by various workers, there are quantitative differences among plant species in this regard [32]: the highest concentrations of $\mathrm{Cr}$ were found in species of the Brassicaceae family [31].

High accumulation in roots may be due to $\mathrm{Cr}$ immobilization in the vacuoles of the root cells [29]. It was demonstrated that $\mathrm{Cr}$ (III) uptake may drastically decrease the stability of Ca-polygalacturonates, high-molecular weight compounds exudated by roots which play a key role in binding cell walls of the rhizodermis and cortical cells. They are present both at the soil-root interface and in the Donnan free space in the apoplast. The collapse of these substances stops the passive translocation of $\mathrm{Cr}$ (III) through the apoplast [35].

The contents of $\mathrm{Cr}$ in plants growing in normal conditions range between 0.02 and $2 \mathrm{mg} / \mathrm{kg}$ and rarely exceed $5 \mathrm{mg} / \mathrm{kg}[26,36]$. Toxicity of $\mathrm{Cr}$ in plants depends on its oxidation state, being $\mathrm{Cr}(\mathrm{VI})$ much more toxic than $\mathrm{Cr}(\mathrm{III})[15,29]$. Cr(III) produces reactive oxygen species and may be toxic at high concentrations: however the low solubility of $\mathrm{Cr}$ (III) in soil generally leads small concentrations of $\mathrm{Cr}$ in plants [15]. The toxic properties of $\mathrm{Cr}(\mathrm{VI})$ are originated from its oxidizing action and formation of free radicals during its reduction to $\mathrm{Cr}(\mathrm{III})$ within the plant cells $[15,29]$.

The food chain is well protected from the possible excesses of $\mathrm{Cr}$ in plants by a system known as "soil-plant barrier": the term was introduced by Chaney to describe "the waste-soil-plant-animal relationship of toxic elements". A soil-plant barrier prevents contamination of the food chain from trace elements limiting their levels in edible plant tissues. Protection is carried out by one or more of the following processes:

- If the element is not soluble in soil, uptake does not occur;

- If the element is absorbed by roots but it is immobilized in fibrous roots, translocation is stopped;

- Phytotoxicity occurs when the element is present in edible plant tissues at concentrations significantly lower than that harmful to humans or animals.

All of these processes apply perfectly to $\mathrm{Cr}$ : indeed $\mathrm{Cr}(\mathrm{VI})$ is readily immobilized in soil by adsorption, reduction, and precipitation processes and only a fraction 
of the total $\mathrm{Cr}$ concentration is available for plant uptake. When this fraction is taken up by plants, quantities superior to $90 \%$ of absorbed $\mathrm{Cr}$ are retained in roots where they are reduced to $\mathrm{Cr}(\mathrm{III})$ species in a short time. Finally phytotoxic levels of $\mathrm{Cr}$ in the plant are less than 10 $\mathrm{mg} / \mathrm{kg}$ [26].

\subsection{Chromium in Animals and Humans}

$\mathrm{Cr}(\mathrm{III})$ is considered an essential element in animals and humans $[37,38]$. Recently it was confirmed that $\mathrm{Cr}(\mathrm{IIII})$ is not carcinogenic [39] and the useful/toxic dose ratio for $\mathrm{Cr}(\mathrm{III})$ is on the order of $1: 10,000$ [38]. It interacts with glucose and lipid metabolism in several animals, including humans: it belongs to the group of substances known as GTF (glucose tolerance factors) which are capable of increasing glucose uptake. In particular $\mathrm{Cr}$ facilitates the interactions between insulin and its specific receptors located in target organs such as muscle and fat tissues [38].

The dietary guidelines for $\mathrm{Cr}$ intake recommended by the Food and Nutrition Board of the US National Academy of Sciences have been diminished from 50 - $200 \mu \mathrm{g}$ day $^{-1}$ for an adult, as recommended by WHO [40], to 35 $\mu \mathrm{g} /$ day for a male, and $25 \mu \mathrm{g} /$ day for a female [41].

Chromium(III) is absorbed with food and, unlike the inorganic compound, only the organic complexes are bioavailable, on the order of $25 \%$ - 30\% [38,42]. Chromium is naturally contained in human food and animal feedstuffs and its amount is highly variable, ranging from $0.01 \mathrm{mg} / \mathrm{kg}$ in milk to $0.25 \mathrm{mg} / \mathrm{kg}$ in cereals (wheat, maize, rye, oats) [43]. It was also investigated the amount of $\mathrm{Cr}$ in arboreal and annual crops fertilized with hydrolyzed residues from tannery [43]: generally the $\mathrm{Cr}$ content in edible parts of all the plants examined was lower than that measured in the controls.

On the other hand $\mathrm{Cr}(\mathrm{VI})$ shows both acute and chronic strong effects of toxicity (it is irritating, allergizing and corrosive) and is considered a potent carcinogen to humans and animals, due to its capacity to react with genetic material $[26,38]$. $\operatorname{Cr}(\mathrm{VI})$ reaches humans and animals mainly through inhalation or industrial contamination [38].

\section{Agronomical and Environmental Aspects}

Nitrogen in solid fertilizers derived from tannery is in the organic form at least for $95 \%$ or more. It is naturally released in soil and made available for plant uptake only after mineralization processes of the organic matter [44]. Consequently $\mathrm{N}$ is slowly released in soil following environmental conditions. Soil temperature and humidity (rainfall, irrigation) and redox potential are the main factors that affect the mineralization process.
The presence of $\mathrm{Cr}(\mathrm{III})$ in these solid fertilizers has worried the public opinion because of possible soil, water and crop contamination. However the risks of environmental pollution by this type of Cr-containing fertilizers are negligible, according with several authors. Increasing amounts of solid fertilizers applied to soil lead to a negligible rise in soil soluble $\mathrm{Cr}$ [2,45-47]. Moreover it was demonstrated that the amount of $\mathrm{Cr}$ leached from soil is insignificant $[45,48]$. Chromium is generally insoluble in soil even when it is released during the mineralization of the organic matter $[2,47,48]$. The organic constituents of the solid fertilizers play an important role in reducing the amount of $\mathrm{Cr}$ available to plants [49]. In experiments where $\mathrm{Cr}(\mathrm{VI})$ was added to the soil, it was immediately reduced to $\mathrm{Cr}(\mathrm{III})$ [9] and no traces of $\mathrm{Cr}(\mathrm{VI})$ were found in the soil collected from various farms where these fertilizers had been used for decades to fertilize the fruit orchards [50].

It was also demonstrated that soil which never had been fertilized with these products was found to have a greater tendency to oxidize $\mathrm{Cr}$ than that soil where these fertilizers had been used for years [51]. Even the main enzymatic activities of the soil did not show any statistically significant differences among the samples [46,50], it was demonstrated that adding these solid fertilizers to soil a higher microbial biodiversity occurs and that the higher microbial activity is maintained in years [52].

Generally, Cr(III) added to soil through these fertilizers is gradually released due to mineralization of the organic matter: this process permits that $\mathrm{Cr}(\mathrm{III})$ is consequently fixed into soil and then unavailable to microbial and plant metabolism $[3,53,54]$. It was demonstrated that the amount of $\mathrm{Cr}$ absorbed by crops is insignificant and if $\mathrm{Cr}$ reaches plant roots, it accumulates in external tissues and only a negligible amount is found in edible parts $[45,53]$.

It was demonstrated throughout several field trials the efficient fertilizing action of these solid fertilizers without any risk to human health, to the contamination of the ground table or to the environment in general and $\mathrm{Cr}$ accumulation in the grains of maize, wheat, rice, bean and radish was not detected, since it precipitates as an oxide which is not available to plants or immobilized in roots that represent a powerful biological barrier [3,54].

\section{Conclusions}

The category of Cr-containing fertilizers includes several products, both mineral and organic. The most known are the fertilizers obtained by transformation of the residues of the tannery industry. As shown they contain $\mathrm{Cr}$ in the trivalent form, that is not toxic and in soil rarely is oxidized to the toxic form of $\mathrm{Cr}(\mathrm{VI})$. Due to their nature not 
hazardous for the environment and human health, legislations of the European Union, United States and of countries such as Italy permit the unlimited use of $\mathrm{Cr}$ containing fertilizers; otherwise some countries do not allow its use because they consider that it may involve a risk for environmental and human health. This seems improper, as previously shown.

Chemical, environmental, agronomical, and legislative aspects of Cr-containing organic fertilizers were discussed in a meeting previously cited at times $[3,11,38,43]$. Despite some preliminary settings, the meeting was considered a milestone in the different countries where the leather industry has developed. These activities are strictly dependent on the use and behavior of $\mathrm{Cr}$, even in the recovery of wastes that are produced. An extensive program of research about the entire production of Cr-containing hides and skins and their byproducts has continued since then, even up to the recovery and reuse of sludge as protein-based sludge, today officially accepted in the Italian law of fertilizers [8].

Moreover the utilization of these fertilizers is agronomic: doses applied to soil vary depending on the crop but generally have a maximum of $1 \mathrm{Mt} / \mathrm{ha}$; higher quantities are not sustainable either agronomically (excess of nitrogen applied), nor economically (high costs).

In particular the solid hydrolyzed protein fertilizers, coming from the residues of the tannery industry, are obtained using selected raw materials deriving by the intermediary phases of tanning. The industrial production process has a high level of standardization and computerized management that reduce the costs: it was estimated that the energy consumption for the production of this kind of organic $\mathrm{N}$ fertilizers is $3.58 \mathrm{GJ} /$ ton per unit of $\mathrm{N}$, while energy consumption for the production of $\mathrm{N}$ mineral fertilizers is $6.42 \mathrm{GJ} /$ ton per unit of $\mathrm{N}$ [55]. Finally this kind of organic $\mathrm{N}$ fertilizers has high agronomic efficiency and they are characterized by slow $\mathrm{N}$ release in soil/growing media-plant systems.

\section{REFERENCES}

[1] S. I. Shupack, "The Chemistry of Chromium and Some Resulting Analytical Problems,” Environmental Health Perspectives, Vol. 92, 1991, pp. 7-11. doi:10.1289/ehp.91927

[2] C. Ciavatta and P. Sequi, "Evaluation of Chromium Release during the Decomposition of Leather Meal Fertilizers Applied to the Soil,” Fertilizer Research, Vol. 19, No. 1, 1989, pp. 7-11. doi:10.1007/BF01080680

[3] C. Ciavatta and C. Gessa, "Chromium-Containing Fertilizers and Their Production,” In: S. Canali, F. Tittarelli and P. Sequi, Eds., Chromium Environmental Issues, Franco-Angeli Editore, Bologna, 1997, pp. 61-82.

[4] C. Ciavatta, L. Vittori Antisari and P. Sequi, "Carat- teristiche Chimiche dei Principali Concimi a Base di Cuoio Torrefatto Disponibili in Italia,” Agricoltura Mediterranea, Vol. 119, 1989, pp. 66-73.

[5] Commission Regulation (EC), “Laying Down Detailed Rules for the Implementation of Council Regulation (EC) No. 834/2007 on Organic Production and Labelling of Organic Products with Regard to Organic Production, Labelling and Control," Commission Regulation (EU) No. 271/201, 2010.

[6] Code of Federal Regulations (CFR), "Standards for the Use or Disposal of Sewage Sludge,” Environment Protection Agency, Title 40 (Protection of Environment), Part 503, 2010.

[7] Federal Register (FR), Vol. 60, No. 206, 1995, pp. 5476354770.

[8] D. Lgs. 29 aprile 2010, n. 75, "Riordino e Revisione della Disciplina in Materia di Fertilizzanti, a Norma dell'Articolo 13 della Legge 7 Luglio 2009, n. 88,” Gazzetta Ufficiale n. 121 del 26 maggio, 2010.

[9] A. Kabata-Pendias and H. Pendias, “Chromium,” In: A. Kabata-Pendias and H. Pendias, Eds., Trace Elements in Soils and Plants, 3rd Edition, CRC Press, Boca Raton, 2011.

[10] C. Ciavatta, L. Vittori Antisari and P. Sequi, “A First Approach to the Determination of the Presence of Humified Materials in Organic Fertilizers," Agrochimica, Vol. 32, 1988, pp. 520-526.

[11] R. L. Chaney, J. A. Ryan and S. L. Brown, "Development of the US-EPA Limits for Chromium in Land-Applied Biosolids and Applicability of these Limits to Tannery By-Product Derived Fertilizers and Other Cr-Rich Soil Amendments,” In: S. Canali, F. Tittarelli and P. Sequi, Eds., Chromium Environmental Issues, Franco-Angeli Editore, Bologna, 1997, pp. 229-295.

[12] Draft-WG Fertilizers, Regulation (EC) 2003/2003 of the European Parliament and of the Council of 13 October 2003 Referred to Fertilizers.

[13] P. Sequi, A. Benedetti, S. Canali and F. Tittarelli, "Aboliti negli Usa i Limiti di Cromo nei Fertilizzanti," L'Informatore Agrario, Vol. 53, No. 9, 1997, pp. 35-37.

[14] National Academy of Sciences, "Distribution of Chromium in the Environment," Committee on Biologic Effects of Atmospheric Pollutants, Chromium: Medical and Biologic Effects of Environmental Pollutants, Washington, 1974.

[15] M. Yibing and P. S. Hooda, "Chromium, Nickel and Cobalt," In: P. S. Hooda, Ed., Trace Elements in Soil, Wiley-Blackwell, New Jersey, 2010.

[16] National Academy of Sciences, "Properties of Chromium," Committee on Biologic Effects of Atmospheric Pollutants, Chromium: Medical and Biologic Effects of Environmental Pollutants, Washington, 1974.

[17] S. E. Fendorf, "Surface Reactions of Chromium in Soils and Waters," Geoderma, Vol. 67, No. 1-2, 1995, pp. 5571. doi:10.1016/0016-7061(94)00062-F

[18] A. M. Ure and M. L. Berrow, "The Elemental Constituents of Soils,” In: H. J. M. Bowen, Ed., Environmental 
Chemistry, Royal Society of Chemistry, London, Vol. 2, 1988, pp. 92-204.

[19] H. J. M. Bowen "Environmental Chemistry of the Elements," Royal Society of Chemistry, Academic Press, London, 1975, pp. 123-125.

[20] D. C. Adriano, “Chromium,” In: D. C. Adriano, Ed., Trace Elements in Terrestrial Environments: Biogeochemistry, Bioavailability, and Risks of Metals, 2nd Edition, Springer-Verlag, New York, 2001, pp. 315-348.

[21] S. P. McGrath, "Chromium and Nickel," In: B. J. Alloway, Ed., Heavy Metals in Soils, 2nd Edition, Blackie Academic and Professional, London, 1995. doi:10.1007/978-94-011-1344-1_7

[22] E. E. Cary, W. H. Allaway and O. E. Olson, "Control of Chromium Concentrations in Food Plants. 2. Chemistry of Chromium in Soils and its Availability to Plants," Journal of Agricultural and Food Chemistry, Vol. 25, No. 2, 1977, pp. 305-309. doi:10.1021/jf60210a049

[23] C. D. Palmer and P. R. Wittbrodt, "Processes Affecting the Remediation of Chromium-Contaminated Sites," Environmental Health Perspectives, Vol. 92, 1991, pp. 2540. doi:10.1289/ehp.919225

[24] G. Choppala, N. Bolan, M. Mallavarapu and Z. Chen, "Sorption and Mobility of Chromium Species in a Range of Soil Types,” In: R. J. Gilkes and N. Prakongkep, Eds., Proceedings of the 19th World Congress of Soil Science, Soil Solutions for a Changing World, Brisbane, 1-6 August 2010, pp. 239-242.

[25] R. J. Bartlett, "Chromium Cycling in Soils and Water: Links, Gap and Methods," Environmental Health Perspectives, Vol. 92, 1991, pp. 17-24. doi:10.1289/ehp.919217

[26] A. M. Zayed and N. Terry, "Chromium in the Environment: Factors Affecting Biological Remediation,” Plant and Soil, Vol. 249, No. 1, 2003, pp. 139-156. doi:10.1023/A:1022504826342

[27] B. R. James, "The Challenge of Remediating ChromiumContaminated Soil," Environmental Science and Technology/News, Vol. 30, No. 6, 1996, pp. 248-251.

[28] E. W. Huffman Jr. and W. H. Allaway, "Chromium in Plants: Distribution in Tissues, Organelles and Extracts, and Availability of Bean Leaf Cr to Animals,” Journal of Agricultural and Food Chemistry, Vol. 21, No. 6, 1973, pp. 982-986. doi:10.1021/jf60190a008

[29] A. K. Shanker, C. Cervantes, H. Loza-Tavera and S. Avudainayama, "Chromium Toxicity in Plants," Environment International, Vol. 31, No. 5, 2005, pp. 739-753. doi:10.1016/j.envint.2005.02.003

[30] S. P. McGrath, "The Uptake and Translocation of Triand Hexavalent Chromium and Effects on the Growth of Oat in Flowing Nutrient Solution and Soil," New Phytologist, Vol. 92, No. 3, 1982, pp. 381-390. doi:10.1111/j.1469-8137.1982.tb03395.x

[31] A. Zayed, C. M. Lytle, J. H. Qian and N. Terry, "Chromium Accumulation, Translocation and Chemical Speciation in Vegetable Crops,” Planta, Vol. 206, No. 2, 1998, pp. 293-299. doi:10.1007/s004250050403
[32] E. E. Cary, W. H. Allaway and O. E. Olson, "Control of Chromium Concentrations in Food Plants. 1. Absorption and Translocation of Chromium by Plants," Journal of Agricultural and Food Chemistry, Vol. 25, No. 2, 1977, pp. 300-304. doi:10.1021/jf60210a048

[33] C. Cervantes, J. Campos-García, S. Devars, F. GutiérrezCorona, H. Loza-Tavera, J. C. Torres-Guzmán and R. Moreno-Sánchez, "Interaction of Chromium with Microorganisms and Plants,” FEMS Microbiology Reviews, Vol. 25, No. 3, 2001, pp. 335-347. doi:10.1111/j.1574-6976.2001.tb00581.x

[34] R. A. Skeffington, P. R. Shewry and P. J. Petersen, "Chromium Uptake and Transport in Barley Seedlings (Hordeum vulgare),” Planta, Vol. 132, No. 3, 1976, pp. 209-214. doi:10.1007/BF00399719

[35] T. Mimmo, L. Cavani, R. Reggiani, C. Marzadori and C. Gessa, "Interactions of Organic and Inorganic Chromium Species with Ca-Polygalacturonate," Biology and Fertility of Soil, Vol. 44, No. 3, 2008, pp. 521-526. doi:10.1007/s00374-007-0238-2

[36] D. R. Sauerbeck, "Plant, Element and Soil Properties Governing Uptake and Availability of Heavy Metals derived From Sewage Sludge," Water, Air and Soil Pollution, Vol. 57-58, No. 1, 1991, pp. 227-237. doi:10.1007/BF00282886

[37] K. N. Jeejeebhoy, R. C. Chu, E. B. Marliss, G. R. Greenberg and A. Bruce-Robertson, "Chromium Deficiency, Glucose Intolerance and Neuropathy Reversed by Chromium Supplementation, in a Patient Receiving Long-term Total Parenteral Nutrition," The American Journal of Clinical Nutrition, Vol. 30, 1977, pp. 531-538.

[38] A. Mordenti and G. Piva, "Chromium in Animal Nutrition and Possible Effects on Human Health,” In: S. Canali, F. Tittarelli and P. Sequi, Eds., Chromium Environmental Issues, Franco-Angeli Editore, Bologna, 1997, pp. 131151.

[39] EFSA (European Food Safety Authority), Panel on Food Additives and Nutrient Sources Added to Food (ANS), "Scientific Opinion on the Safety of Trivalent Chromium as a Nutrient Added for Nutritional Purposes to Foodstuffs for Particular Nutritional Uses and Foods Intended for the General Population (Including Food Supplements)," EFSA Journal, Vol. 8, No. 1732, 2010, pp. 1-46.

[40] WHO (World Health Organization), Regional Office for Europe, “Inorganic Pollutants,” In: Air Quality Guidelines for Europe, 2nd Edition, WHO Regional Publications, European Series, No. 91, Copenaghen, 2000, pp. 123-135.

[41] J. B. Vincent, "Recent Advances in the Nutritional Biochemistry of Trivalent Chromium," Proceedings of the Nutrition Society, Vol. 63, No. 1, 2004, pp. 41-47. doi:10.1079/PNS2003315

[42] E. G. Offenbacher, H. Spencer and H. J. Dowling, "Metabolic Chromium Balances in Men," The American Journal of Clinical Nutrition, Vol. 44, 1986, pp. 77-82.

[43] G. Santoprete, "Total Chromium Content in Foodstuffs and Evaluation of the Average Amount of Chromium Uptake,” In: S. Canali, F. Tittarelli and P. Sequi, Eds., 
Chromium Environmental Issues, Franco-Angeli Editore, Bologna, 1997, pp. 153-179.

[44] P. Sequi, C. Ciavatta and L. Vittori Antisari, "Organic Fertilizers and Humification in Soil,” In: R. A. Baker, Ed., Organic Substances and Sediments in Water, Vol. 1. Humic and Soil, Lewis Publ. Inc., Chelsea, 1991, pp. 351367.

[45] S. Silva, "Impiego di Concimi Organici a Base di Cuoio Torrefatto, Determinazione delle Concentrazioni di Cromo nei Vegetali e Valutazione delle Possibilità di Inquinamento delle Falde Freatiche,” Annali della Facoltà di Agraria dell'Università Cattolica del Sacro Cuore, Sede di Piacenza, Vol. 17, 1977, pp. 1-38.

[46] A. Benedetti, M. T. Dell'Abate and F. Alianiello, "Mobility and Bioavailability of Chromium in the Soil," Fresenius Environmental Bulletin, Vol. 1, 1992, pp. 323-329.

[47] M. Govi, C. Ciavatta, L. Sitti, G. Bonoretti and C. Gessa, "Influence of Leather Meal Fertilizer on Soil Organic Matter: A Laboratory Study,” Fertilizer Research, Vol. 44, 1996, pp. 65-72. doi:10.1007/BF00750693

[48] C. Giacometti, L. Cavani, P. Gioacchini, C. Ciavatta and C. Marzadori, "Soil Application of Tannery Land Plaster: Effects on Nitrogen Mineralization and Soil Biochemical Properties,” Applied Environmental Soil Science, 2011, 9 p.

[49] S. Silva and B. Beghi, "Problemi Inerenti l'Impiego di Concimi Organici Contenenti Cromo,” Annali della
Facoltà di Agraria dell'Università Cattolica del Sacro Cuore, Sede di Piacenza, Vol. 19, 1979, pp. 31-47.

[50] A. Benedetti and C. Ciavatta, "Alcuni Aspetti Relativi alla Produzione e all'Impiego Agronomico dei Concimi a Base di Cuoio Idrolizzato ed al Cromo in Essi Contenuto,” Agricoltura e Ricerca, Vol. 170, 1998, pp. 63-72.

[51] C. Ciavatta, D. Montecchio e P. Sequi, “Applicazione di un Test Rapido per la Determinazione del Potere Ossidante del Terreno nei Confronti del Cromo,” Acqua Aria, No. 9, 1992, pp. 875-879.

[52] S. Mocali, "Studio della Diversità Microbica in Suoli Concimati con Cuoio Idrolizzato,” Ph.D. Thesis, Università degli Studi di Firenze, Florence, 2003.

[53] A. Benedetti and M. T. Dell'Abate, "Studi Preliminari sull'Effetto del Cromo sull'Attività Microbiologica del Terreno. Interazione Cromo-Sostanza Organica,” Istituto Sperimentale per la Nutrizione delle Piante, Vol. 14, 1988, pp. 1-15.

[54] S. Silva, C. Baffi and G. M. Beone, "Agronomical Trials with the Use of Chromium-Containing Fertilizers,” In: S. Canali, F. Tittarelli and P. Sequi, Eds., Chromium Environmental Issues, Franco-Angeli Editore, Bologna, 1997, pp. 83-100.

[55] Document on Best Available Techniques for the Manufacture of Large Volume Inorganic Chemicals Ammonia, Acids and Fertilizers, 2007. 